\title{
Morphogenesis of the rhea (Rhea americana) respiratory system in different embryonic and foetal stages ${ }^{1}$
}

\author{
Renata P. Sousa ${ }^{2}$, Hatawa M. de A. Monteiro², Dayseanny de O. Bezerra ${ }^{2}$, Leticya \\ L. da S. Soares ${ }^{2}$, Antônio C. Assis Neto ${ }^{3}$, Rose E.G. Rici ${ }^{3}$, Aírton M. Conde Júnior ${ }^{4}$ \\ and Maria A.M. de Carvalho ${ }^{2 *}$
}

\begin{abstract}
Sousa R.P., Monteiro H.M.A., Bezerra D.O., Soares L.L.S., Assis Neto A.C., Rici R.E.G., Conde Junior A.M. \& Carvalho M.A.M. 201,8. Morphogenesis of the rhea (Rhea americana) respiratory system in different embryonic and foetal stages. Pesquisa Veterinária Brasileira 38(1):154-166. Departamento de Morfofisiologia Veterinária, Centro de Ciências Agrícolas, Universidade Federal do Piauí, Campus Ministro Petronio Portela, Ininga, Teresina, PI 64049-550, Brazil. E-mail: mcelina@ufpi.edu.br

The rhea (Rhea americana) is an important wild species that has been highlighted in national and international livestock. This research aims to analyse embryo-foetal development in different phases of the respiratory system of rheas. Twenty-three embryos and foetuses were euthanized, fixed and dissected. Fragments of the respiratory system, including the nasal cavity, larynx, trachea, syrinx, bronchi and lungs, were collected and processed for studies using light and scanning electron microscopy. The nasal cavity presented cubic epithelium in the early stages of development. The larynx exhibited typical respiratory epithelium between 27 and 31 days. The trachea showed early formation of hyaline cartilage after 15 days. Syrinx in the mucous membrane of 18-day foetuses consisted of ciliated epithelium in the bronchial region. The main bronchi had ciliated epithelium with goblet cells in the syringeal region. In the lung, the parabronchial stage presented numerous parabronchi between 15 and 21 days. This study allowed the identification of normal events that occur during the development of the rhea respiratory system, an important model that has not previously been described. The information generated here will be useful for the diagnosis of pathologies that affect this organic system, aimed at improving captive production systems.
\end{abstract}

INDEX TERMS: Rhea, Rhea Americana, respiratory system, embryonic stage, foetal stage, avian, embryonic development, histology, organogenesis.

RESUMO.- [Morfogênese do sistema respiratório da ema (Rhea americana) em diferentes estágios embrionários e fetais.] A ema (Rhea americana) representa importante espécie silvestre que vem se destacando na pecuaria

\footnotetext{
${ }^{1}$ Received on February 25, 2017.

Accepted for publication on June 30, 2017.

${ }^{2}$ Departamento de Morfofisiologia Veterinária, Centro de Ciências Agrícolas, Universidade Federal do Piauí (UFPI), Campus Ministro Petronio Portela, Ininga, Teresina, PI 64049-550, Brazil. *Corresponding Author: mcelina@ufpi.edu.br

${ }^{3}$ Departamento de Cirurgia, Setor de Anatomina de Animais Domésticos e Selvagens, Faculdade de Medicina Veterinária e Zootecnia, Universidade de São Paulo (USP), Av. Prof. Dr. Orlando Marques de Paiva 87, São Paulo, SP 05508-270, Brazil.

${ }^{4}$ Departamento de Morfologia, Centro de Ciências da Saúde, UFPI, Av. Frei Serafim 2280, Teresina, PI 64001-020, Brazil.
}

nacional e internacional. Esta pesquisa objetiva analisar o desenvolvimento embrionário-fetal, em diferentes fases, do sistema respiratório de emas. Vinte e três embriões e fetos foram eutanasiados, fixados e dissecados. Fragmentos do sistema respiratório: cavidade nasal, laringe, traqueia, siringe, brônquios e pulmões, foram coletados e processados para estudos por meio de microscopia de luz e microscopia eletrônica de varredura. A cavidade nasal apresentou, nas primeiras fases de desenvolvimento, epitélio estratificado cúbico. A laringe exibiu epitélio respiratório típico entre 27 e 31 dias. A traqueia aos 15 dias apresentou início de formação da cartilagem hialina. Na siringe a túnica mucosa de fetos de 18 dias e formada por epitélio estratificado ciliado na região bronquial. Os brônquios principais apresentavam epitélio estratificado ciliado com células caliciformes na região siringeal. No pulmão, o estágio parabronquial 
apresentou numerosos parabrônquios entre 15 a 21 dias. Este estudo permitiu a identificação de eventos normais que ocorrem durante o desenvolvimento do sistema respiratório de emas, importante modelo ainda não descrito. As informações geradas serão úteis para o diagnóstico de patologias que acometem este sistema orgânico, visando a melhoria dos sistemas de produção em cativeiro.

TERMOS DE INDEXAÇÃO: Sistema respiratório, ema, Rhea americana, estágio embrionário, estágio fetal, aves, desenvolvimento embrionário, histologia, organogenese.

\section{INTRODUCTION}

Brazil has the world's largest biodiversity and one of the richest avifaunas in the world. The rhea (Rhea americana) is among the oldest birds on the South American continent, inhabiting the countryside areas and savannas (Sick 2001). It is a large, wild bird, of the order Rheiforme, family Rheidae, genus Rhea, belonging to the group of ratites birds, which includes the ostriches, emus, rheas, cassowaries, kiwis (Dani 1993, Sigrist 2009) and the present-day ratites, the most primitive birds from a phylogenetic point of view (Sick 2001).

In general, the respiratory system of birds, as well as that of other vertebrates, has the importante function of capturing oxygen and releasing carbon dioxide, providing the gas exchange that is fundamental to cellular metabolism. This system is also responsible for the elimination of heat, detoxification metabolism, production of chemical messengers and vocalization (Macari 1994).

Understanding the morphological aspects of embryonic and foetal development in rheas is important for the breeding of this species in captivity, given that this wild bird is representative of the large species with zootechnical potential for national and international livestock (Dani 1993).

Studies on the external morphology of embryos and foetuses of rheas (Rhea americana) at diferente incubation times in addition to the histological features during the development of the birds' digestive tract were made by Monteiro (2014). However, there is still a lack of information about the morphology of the respiratory system of this species during embryonic and foetal development, a study of great importance, considering that they are the components of this system frequently affected by diseases that often cause heavy reproductive losses, also resulting in economic losses to producers.

The first morphological sign of respiratory tract development observed in chicken embryos (Gallus gallus domesticus) is the emergence of the laryngeotracheal groove, which becomes visible on the floor of the midline of the pharynx from the 3rd day of incubation, presenting flow to the fourth pharyngeal arch. This groove becomes closed along most of the length of the pharynx, forming a tube, the trachea, which remains open to the pharynx in its forward end, constituting the glottis (Bellairs \& Osmond 2005). According to Alcântara et al. (2013) on the fourth day of embryonic development of chicken embryonic development, the organs of the respiratory system are formed by disorganized and undifferentiated tissue, with complete differentiation observed after 10 days of incubation.

Some studies have been performed to describe the morphological characteristics of the respiratory organs, mainly using domestic chicken Gallus gallus domesticus as an experimental model (Alcântara et al. 2013, Kang et al. 2013, Lopez et al. 2000, Maina 2003a). In addition to this, other species of birds, like the ostrich Struthio camelus (Abidu-Figueiredo et al. 2012, Makanyaa et al. 2012, Yildiz et al. 2003), the parakeet Melopsittacus undulatus (Smith et al. 1987), the quail Coturnix coturnix japonicum (Cevik-Demirkan et al. 2007), the Meleagris gallopavo turkey (Khaksar et al. 2012) and the pelican Pelicanus conspicillatus (Runciman et al. 2005) have served as models for studies in this area.

The lack of more detailed data on the morphogenesis of the respiratory system of birds has undoubtedly hindered the decisive perception of its functional structure (Maina 2003a).

The aim of this study was to analyse the microscopic aspects of the respiratory system of the rhea (Rhea americana), a model that has not yet been described at different stages of embryo-foetal development. The information generated here will be of great importance for the identification of the ontogenetic pattern of the respiratory system and will allow other investigations related to conditions that can generally occur in this system, aimed at improving captive production systems.

\section{MATERIALS AND METHODS}

We used 23 rhea embryos and foetuses from the Study and Conservation of Wild Animals, NEPAS (Registration Brazilian Institute of Environment and Renewable Natural Resources, IBAMA, no. 02/08-618, CTF no. 474064, SISBI0 no. 35374-1) of the Federal University of Piauí. The methodology of these research protocols were approved by the Ethics Committee on Animal Experimentation (CEEA), UFPI, no. 029/12.

The feeding of breedstock was based on commercial feed (crude protein min - $160 \mathrm{~g}$, ether extract min - 25g, max mineral material $-120 \mathrm{~g}$, fibrous matter max - $160 \mathrm{~g}$, calcium max - 25g, phosphorus min - 8g), grass Brachiaria, fruit all the time and water ad libitum.

The eggs were collected daily from July 2012 to September 2013, from different nests, always at dawn and transported to the Integrated Center of Morphology and Research Stem Cell (NUPCelt) of the Federal University of Piauí, where they were disinfected with sodium hypochlorite solution at $0.1 \%$ and incubated identified at an adjustable temperature of $37.5^{\circ} \mathrm{C}$ and average relative humidity of $45 \%$.

Age " 0 " was defined as the time at which the eggs were placed in incubation. Embryos and foetuses were collected from the ninth day of incubation to the fifteenth day of development; after this period, opening was conducted on days 18, 21, 27, 30 and 31.

The embryos and foetuses were euthanized by administration of potassium chloride $(100 \mathrm{mg} / \mathrm{kg})$ via intracelomic after previous anaesthesia overdose of ketamine $(40 \mathrm{mg} / \mathrm{kg})$ associated with xylazine $(4 \mathrm{mg} / \mathrm{kg}$ ) similar to the method described by Pollock et al. (2005). The embryos and foetuses were washed with saline solution and fixed in $5 \%$ buffered formalin. 
For histological studies after fixation, two animals of each age, except for 31 days, were dissected and the following fragments of the respiratory system were collected: nasal cavity, larynx, trachea, bronchi, lung and syrinx. The samples were dehydrated in a series of increasing concentrations of ethanol $(70 \%$ to $100 \%$ ), diaphanized in xylene and embedded in paraffin. Fragments of the nasal cavities from the 21-, 27-, 30- and 31day foetuses passed prior to the process of decalcification with formic acid 7\%. The 21-day foetus for a period of $24 \mathrm{~h}$, and other foetuses, for five days with only one change after three days and then were processed. The blocks were cut in the microtome into 5 - $\mu$ m-thick sections and stained with haematoxylin-eosin (HE). The slides were examined microscopically and photographic records with digital virtual microscope system for five blades, VS120-S5, Olympus brand.

In the analysis by scanning electron microscopy (SEM), the samples were fixed in formalin $5 \%$, post-fixed in osmium tetroxide $1 \%$, dehydrated in series of alcohol (50\%, 70\%, 90\% and 100\%), brought to the critical point (Balzers CPD 020 (FMVZ-USP), bonded with carbon glue metal aluminium bases (stub) and sputted with gold in the sputter machine Emitech K550 (FMVZ-USP). The samples were analysed by scanning electron microscopy LEO 435VP (FMVZ-USP).

The developing animals were characterized according to Almeida et al. (2015): embryos (MS) were those with up to 10 days of incubation and foetuses (FE), from 11 days of incubation onwards.

\section{RESULTS}

The respiratory system of the rhea consists of organs that perform the functions already known as transport and gas exchange. However, during the embryonic and foetal periods are observed changes in cellular organization to the functional morphological formation of each organ.

The organ morphogenesis of the respiratory system of rheas has been described, taking into account the age groups with similar characteristics, considering embryos as those with up to 10 days of incubation (EM10) and foetuses as 11 days of incubation onward (FE11). In this system, there were characterized microscopically six organs, namely: the nasal cavity, larynx, trachea, syrinx, bronchi and lungs. We could not characterize the air sacs at the developmental stages analysed. Macroscopic aspects of nasal cavity, larynx, trachea and lung of rhea with 27 days are identified in Figure 1.

\section{Nasal cavity}

The nasal cavity EM9, EM10 and FE11 presented mucosa with distinct layers of cells with predominance of cubical cells. From EM9, it was possible to observe the nasal cavity in communication with the oral cavity and the lamina propria consisted of loose mesenchyme (Fig.2A).

Turbinates were observed from the FE13 foetal stage
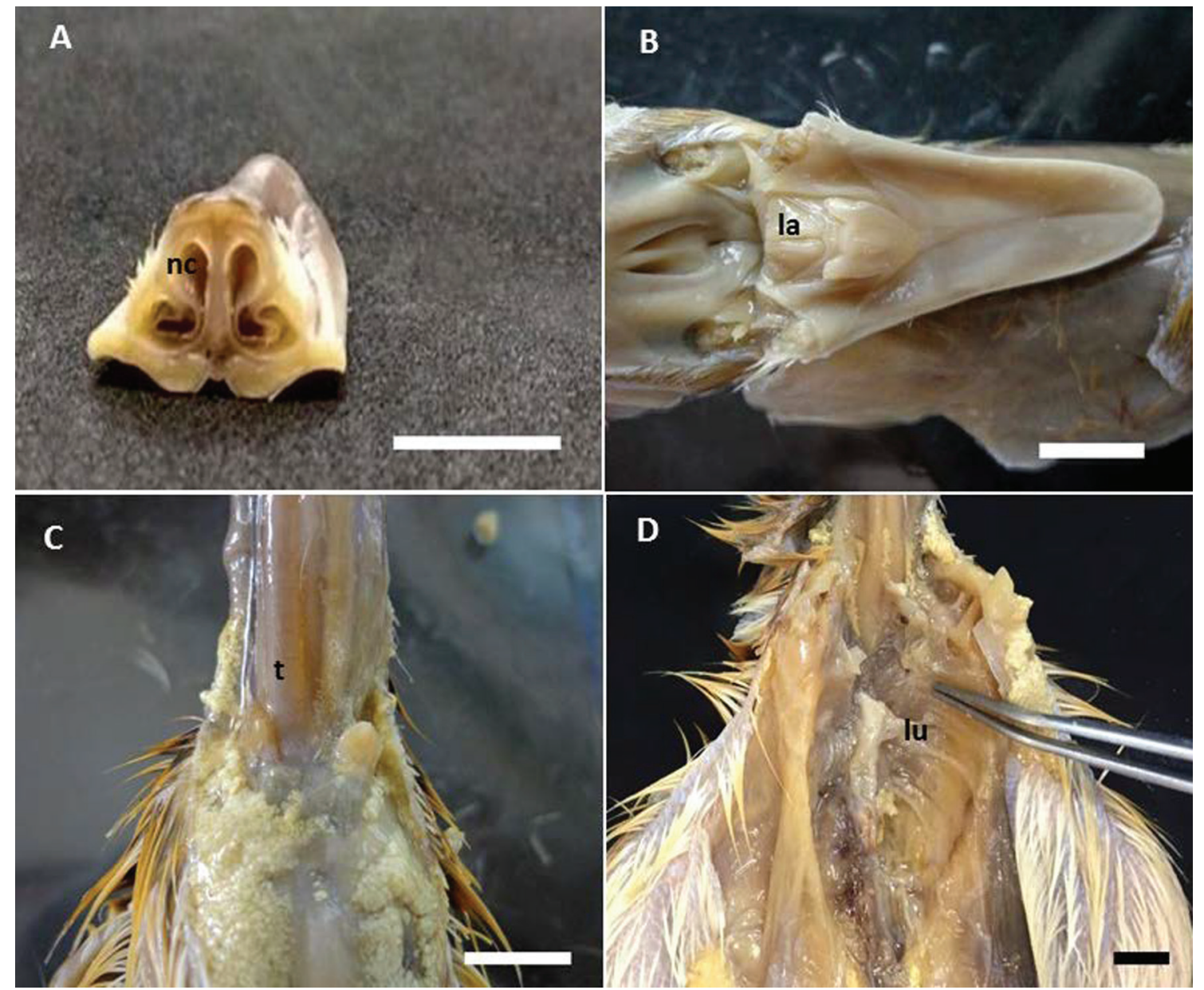

Fig.1. (A-D) Macroscopic aspects of the respiratory system organs of Rhea americana with 27 days of development of the nasal cavity (nc) in cross section, larynx (la), trachea $(\mathrm{t})$ and lung (lu) respectively. Bar $=1 \mathrm{~cm}$. 



Fig.2. Nasal cavity of Rhea americana during foetal development at different ages. (A-F) The nasal cavity at 11, 13, 15, 21, 27 and 30 days respectively. (A) The oral cavity is in communication with nasal cavity the (OC-NC); nasal meatus (NM). HE, Bar = 200 $\mu$ m. (B) Middle nasal concha (MC) in the form of parchment and early in the histogenesis of hyaline cartilage (HC), epithelium (EP), nasal meatus (NM). HE, Bar $=100 \mu \mathrm{m}$. (C) Nasal rostral concha (RC) in a "C", nasal septum (NS). HE, Bar $=200 \mu \mathrm{m}$. (D) Note the middle nasal concha (MC) further developed, nasal meatus (NM), submucosa consists of loose mesenchyme (m), intramembranous ossification (IO) clear. $\mathrm{HE}, \mathrm{Bar}=200 \mu \mathrm{m}$. (E) The epithelium of the middle nasal concha region displays reorganization, becoming pseudostratified (EP) showing groups of cilia (ci) and formation of intraepithelial glands (G), mesenchyme (m), blood vessels (bv). HE, Bar = 50 $\mu \mathrm{m}$. (F) In the region of the rostral concha, the epithelium (EP) has a stratified keratinized surface (k) and column of cells (col). HE, Bar $=20 \mu \mathrm{m}$. 


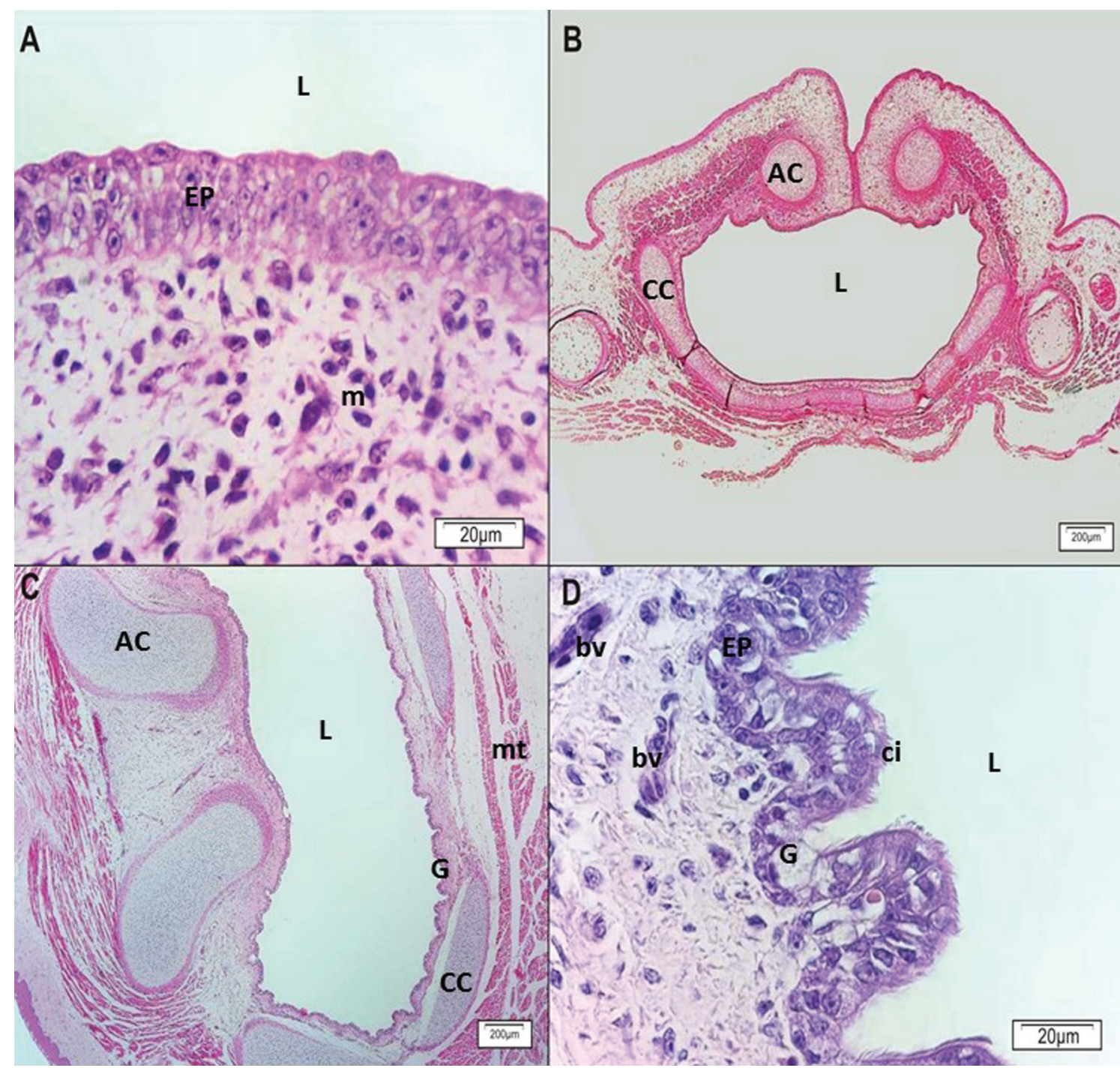

Fig.3. The larynx of Rhea americana foetuses at different ages of development. (A-D) Larynx at 18, 21, 30 and 31 days respectively. (A) Note the cubic epithelium (EP) and mesenchymal (m). HE, Bar $=20 \mu \mathrm{m}$. (B) Arytenoid cartilages (AC) and cricoid cartilage (CC), lumen (L). HE, Bar $=200 \mu \mathrm{m}$. (C) Lumen (L) is irregular due to the formation of intraepithelial glands (G), arytenoid cartilage (AC), cricoid cartilage (CC), muscular tunica (mt). HE, Bar $=200 \mu \mathrm{m}$. (D) The pseudostratified epithelium (EP) with of cilia (ci), intraepithelial glands (G), lumen (L), blood vessels (bv). HE, Bar $=20 \mu \mathrm{m}$.

onward. At this stage, the middle nasal concha, distinguished by way of scroll display, presented cubic epithelium surrounded by mesenchymal tissue initiating differentiation hyaline cartilage (Fig.2B). In addition, it was possible to visualize regions of intramembranous ossification at this stage. In FE15, the nasal turbinate had a Form "C" rostral concha characteristic (Fig.2C). The mucosa also appeared coated with cubic epithelium cell layers that were well defined on the surface (Fig.8A) and had higher baseline cellularity.

In FE18 and FE21, the mucosa displayed more uniform layers of cubical cells and submucosa covered by loose mesenchyme. The progression of the process of intramembranous ossification at these ages was more evident in the higher number of mesenchymal cells that were differentiated into osteocytes and osteoblasts (Fig.2D). Already in FE18, could be observed the source region of the middle nasal concha, appearing to emerge from the dorsal wall of the nasal cavity.

The coating of the middle nasal concha displayed cellu- lar reorganization, with FE27 presenting pseudostratified ciliated epithelium and goblet cells permeated by intraepithelial mucous glands (Fig.2E). The typical submucosa was formed by loose connective tissue and intramembranous ossification in the dorsal and ventral region. In the rostral region, the FE30 concha also underwent reorganization, presenting cells with the mucosal surface epithelium and a wrinkled appearance with the presence of keratinized stratified columns of cells and a basal layer of cuboidal cells (Fig.2F). When observed under SEM, this region had superficial cells in the process of desquamation, highlighting the keratinized epithelium (Fig.8B). The submucosa was highly vascularized in the rostral concha region.

\section{Larynx}

Histological identification of the larynx was possible from FE15: the laryngeal mucosa was lined by stratified cuboidal epithelium with different cell layers consisting of 
cubic and elongated cells in the apical and basal regions. The tunica submucosa of mesenchymal tissue was observed in FE18 and FE21 (Fig.3A); in the latter case, the blade consisted of mesenchymal tissue of more dense collage- nous fibres near the arytenoid cartilages (Fig.3B). Among the muscle bundles could be observed nerve endings and small blood vessels.

At foetal ages between FE27 and FE31 was observed

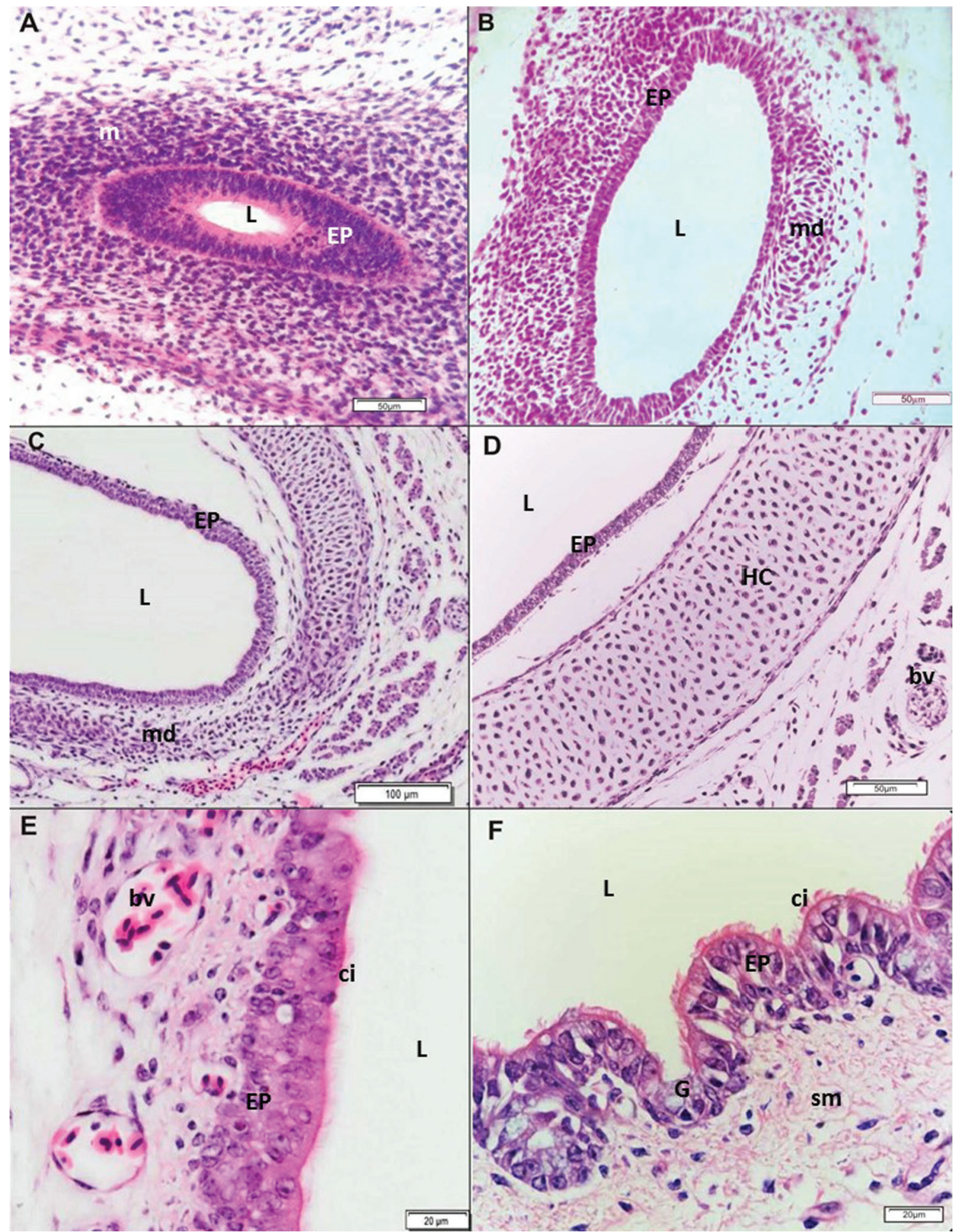

Fig.4. The trachea of embryos and Rhea americana foetuses at different ages of development. (A-F) Trachea at 9, 15, 18, 21, 27 and 31 days respectively. (A) Epithelium (EP), mesenchyme (m), lumen (L). HE, Bar $=50 \mu \mathrm{m}$. (B) Mesenchymal differentiation (md) characteristic in the histogenesis of hyaline cartilage, epithelium (EP), lumen (L). HE, Bar $=50 \mu \mathrm{m}$. (C) Stratified epithelium (EP), progression of mesenchymal differentiation (md), lumen (L). HE, Bar $=100 \mu \mathrm{m}$. (D) Hyaline cartilage (HC), epithelium (EP), lumen (L), blood vessel (bv). HE, Bar $=50 \mu \mathrm{m}$. (E) Pseudostratified epithelium (EP) with cilia (ci), blood vessels (bv). HE, Bar = 20 $\mu \mathrm{m}$. (F) Formation of intraepithelial mucous glands (G), pseudostratified epithelium (EP) with cilia (ci), lumen (L), submucosa (sm). HE, Bar = 20 $\mu$ m. 
respiratory epithelium consisting of pseudostratified ciliated to goblet cells. In addition, a large number of mucusproducing intraepithelial glands were observed in the epithelium (Fig.3D and 8C). Anchored to this was the lamina propria and below, the loose vascularized connective tissue (Fig.3C,D). The cartilaginous skeleton of the larynx had two arytenoid cartilage and cricoid being surrounded by dense connective tissue (perichondrium). The muscular coat had layers of longitudinal and transverse muscles (Fig.3C).

\section{Trachea}

The tracheal epithelium displayed similarities between EM9 and FE15, presenting stratified, undifferentiated, predominantly cubic cells (Fig. 4A and B). The development of mesenchymal cells was evident in the whole extension of the organ wall at this age, with greater cellularity in FE13 and early differentiation process in cartilage FE15 (Fig.4B).
In FE18, incomplete rings of hyaline cartilage were observed, appearing formed and surrounded by the perichondrium in FE21. At this stage, it was possible to confirm the presence of a complete pipe composed of cartilaginous rings characteristic of birds (Fig.8D). Further histologic similarities were found between FE18 and FE21, both of which presented mucosa comprising layers of cuboidal cells (Fig.4C,D) and between FE27 and FE31, which presented ciliated, pseudostratified epithelium with goblet cells and vascular lamina propria (Fig.4E). On the surface of the mucosa, epithelial cells had thicker hair, as can be seen in figure $8 \mathrm{E}$. In FE 31, the mucosa intraepithelial glands are visible (Fig.4F).

\section{Syrinx}

The mucous membrane of the syrinx in the FE18 and FE21 specimens was formed by stratified epithelium with

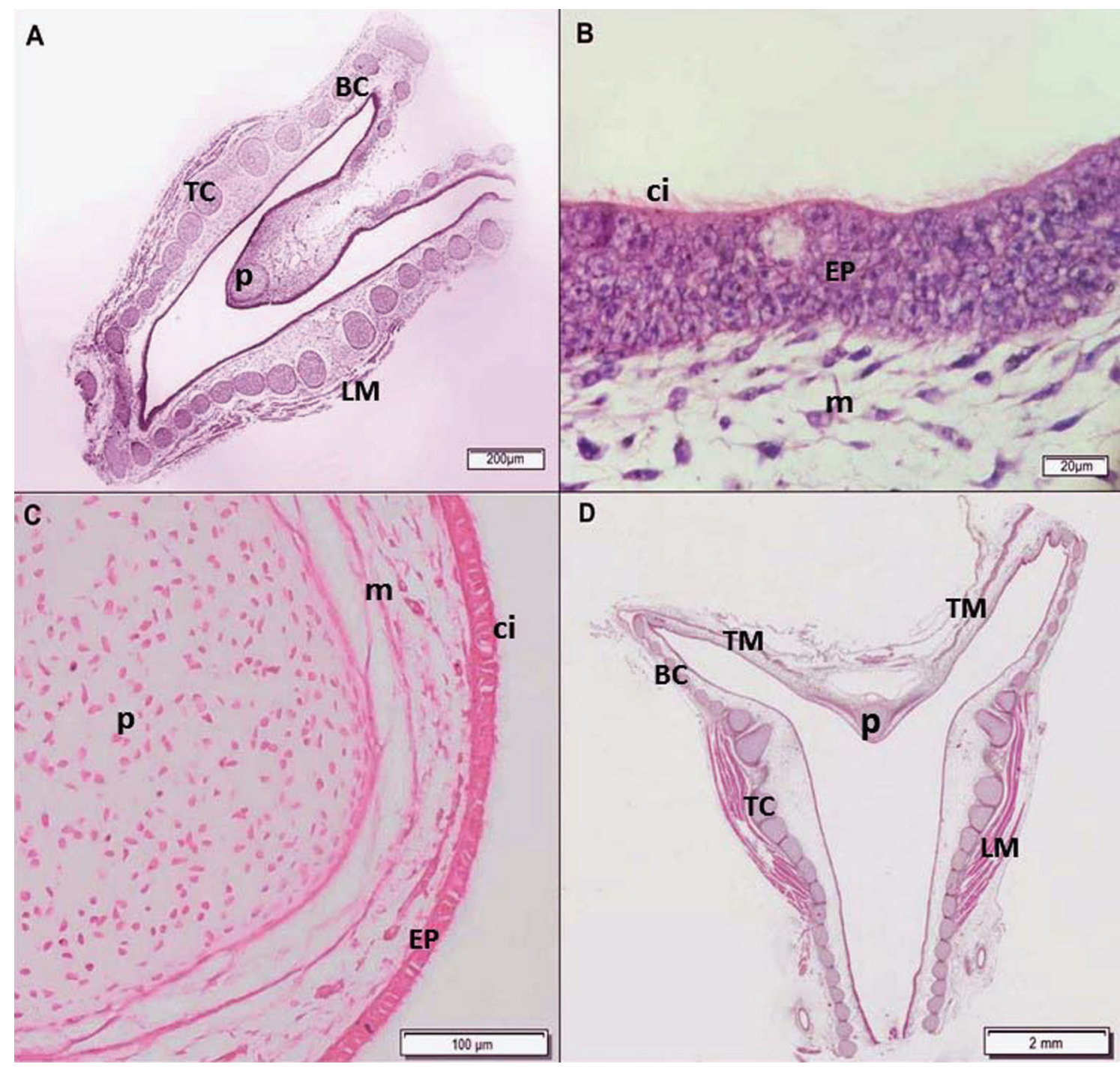

Fig.5. Rhea americana foetuses syrinx at different ages of development. (A-B) Syrinx at 18 days. (C-D) With 27 and 30 days respectively. (A) Note the thin layer of longitudinal muscle (LM), bronchiosyringeal cartilage (BC), tracheosyringeal cartilage (TC), pessulus cartilaginous (p). HE, Bar $=200 \mu \mathrm{m}$. (B) Stratified epithelium (EP) with cilia (ci), mesenchyme (m). HE, Bar = 20 $\mathrm{mm}$. (C) Epithelium becomes pseudostratified (EP), ciliated (ci), pessulus (p), loose mesenchyme (m). HE, Bar = 100 $\mu$ m. (D) Longitudinal muscles are more evident (LM), bronchiosyringeal cartilage (BC), tracheosyringeal cartilage (TC), tympanic membrane (TM), pessulus (p). HE, Bar $=2 \mathrm{~mm}$. 


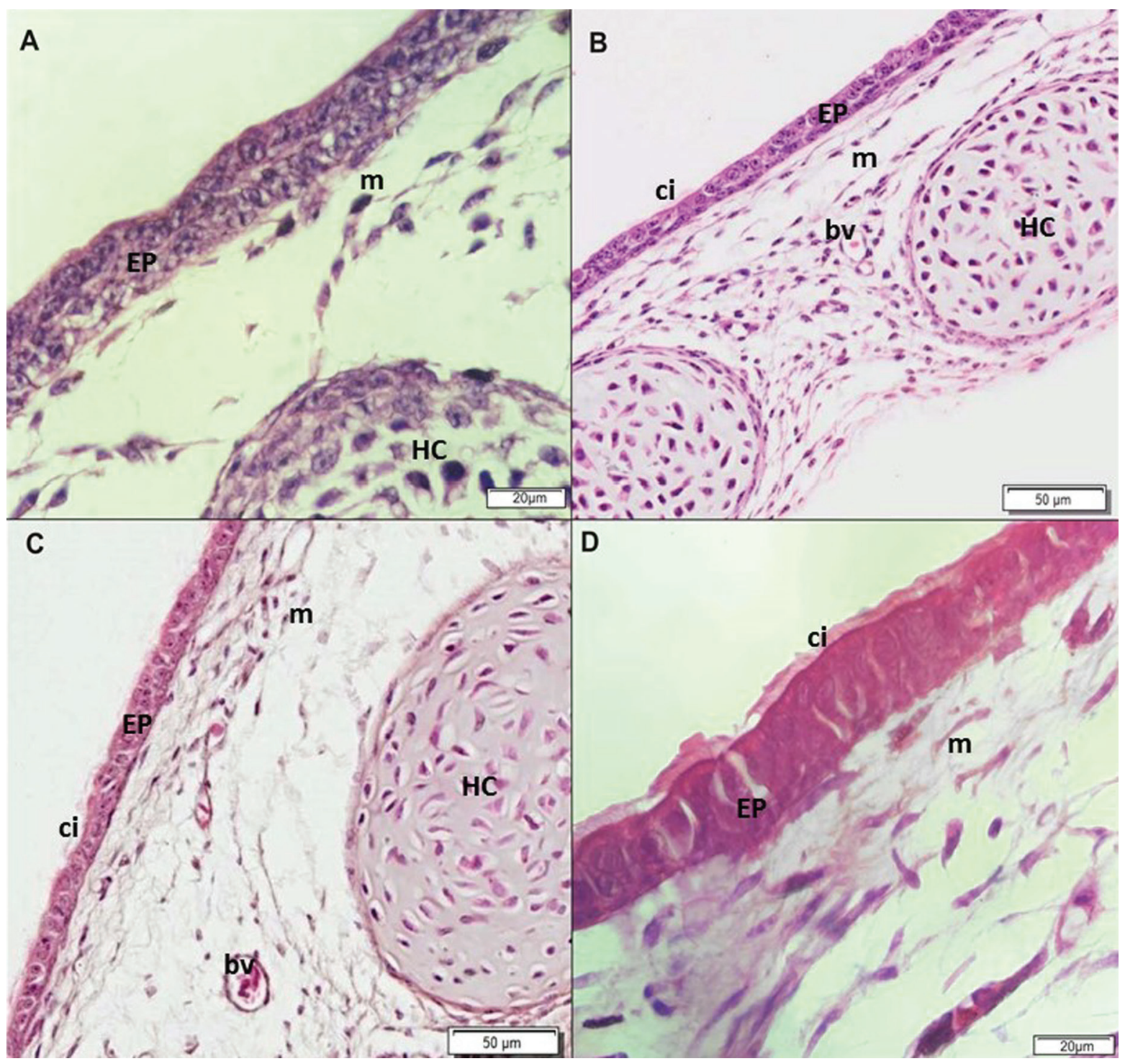

Fig.6. Bronchi of Rhea americana foetuses at different ages of development. (A-D) With 18, 21, 27 and 31 days respectively. (A) Stratified epithelium (EP), lamina propria consists of loose mesenchyme (m), hyaline cartilage forms the bronchial ring $(\mathrm{HC})$. $\mathrm{HE}$, Bar $=20 \mu \mathrm{m}$. (B) Isolated cilia (ci), loose mesenchyme (m), blood vessels (bv), hyaline cartilage (HC). HE, Bar = 50 $\mu$ m. (C) The pseudostratified epithelium (EP) with ciliated cells (ci), mesenchyme (m), hyaline cartilage (HC). HE, Bar = 50 $\mu$. . (D) Cilia are evident (ci), pseudostratified epithelium (EP) mesenchyme (m). HE, Bar $=20 \mu \mathrm{m}$.

the presence of cilia in the bronchial region (Fig.5B) and more evident in the SEM (Fig.8F) and stratified cubic tracheal region. In these developmental stages, the tunica adventitia, the outermost layer, consisted of loose mesenchyme in small vessels and nerves (Fig.5A,B).

Between FE27 and FE31, the mucous membrane of the syrinx was lined by pseudostratified ciliated epithelium with goblet cells (Fig.5C). The tunica adventitia was composed of loose mesenchymal tissue with fat cells, blood vessels and nerves. The four rings of tracheosyringeal cartilage that formed the tympanic region differed from the others due to their larger size and adjacency to longitudinal muscles. In the bronchiosyringeal region was the internal tympanic membrane and centre pessulus, a cartilaginous structure-shaped wedge that divided the lumen of the trachea into the two main bronchi (Fig.5D and 8G).

\section{Bronchi}

As for the bronchi, only the core will be described separately, being observed from the bronchiosyringeal region. The intrapulmonary bronchi and secondary and tertiary bronchi (parabronchi) will be described along with the lungs.

In FE18 and FE21, the mucosa of the main bronchi showed epithelium with goblet cells and some groups of cilia in the syringeal region (Fig.6A,B), identified in detail at the level of electron microscopy (Fig.8F). Cellularized mesenchyme next to the cartilage was seen in the presence of small vessels and nerves (Fig.6B). The lamina propria was composed of vascularized loose mesenchyme. The layer was quite cellularized with adventitious vascularization.

From FE27, the main bronchi showed pseudostratified ciliated epithelium with goblet cells. The lamina propria consisted of vascularized loose mesenchyme (Fig.6C,D). 


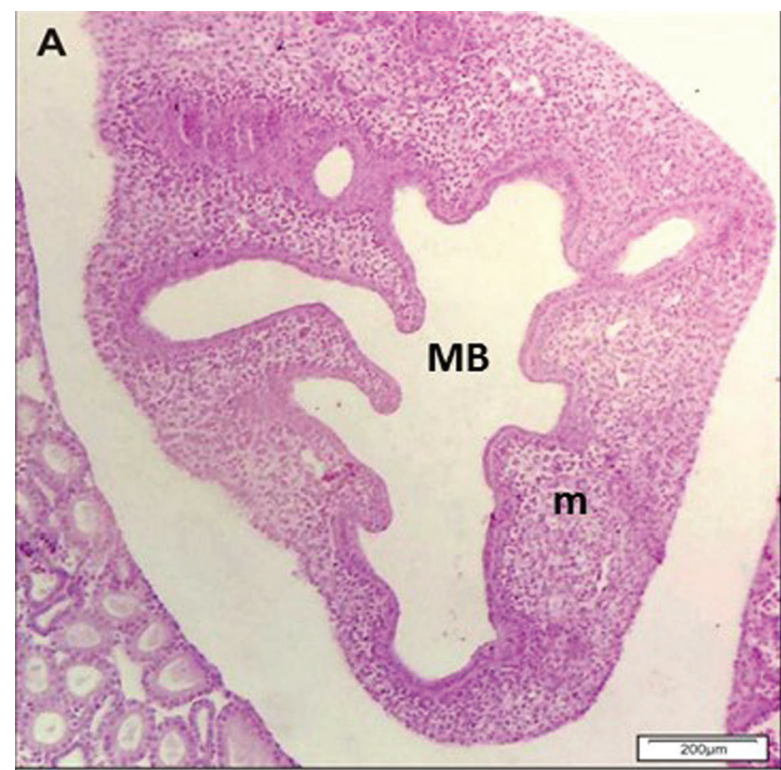

B
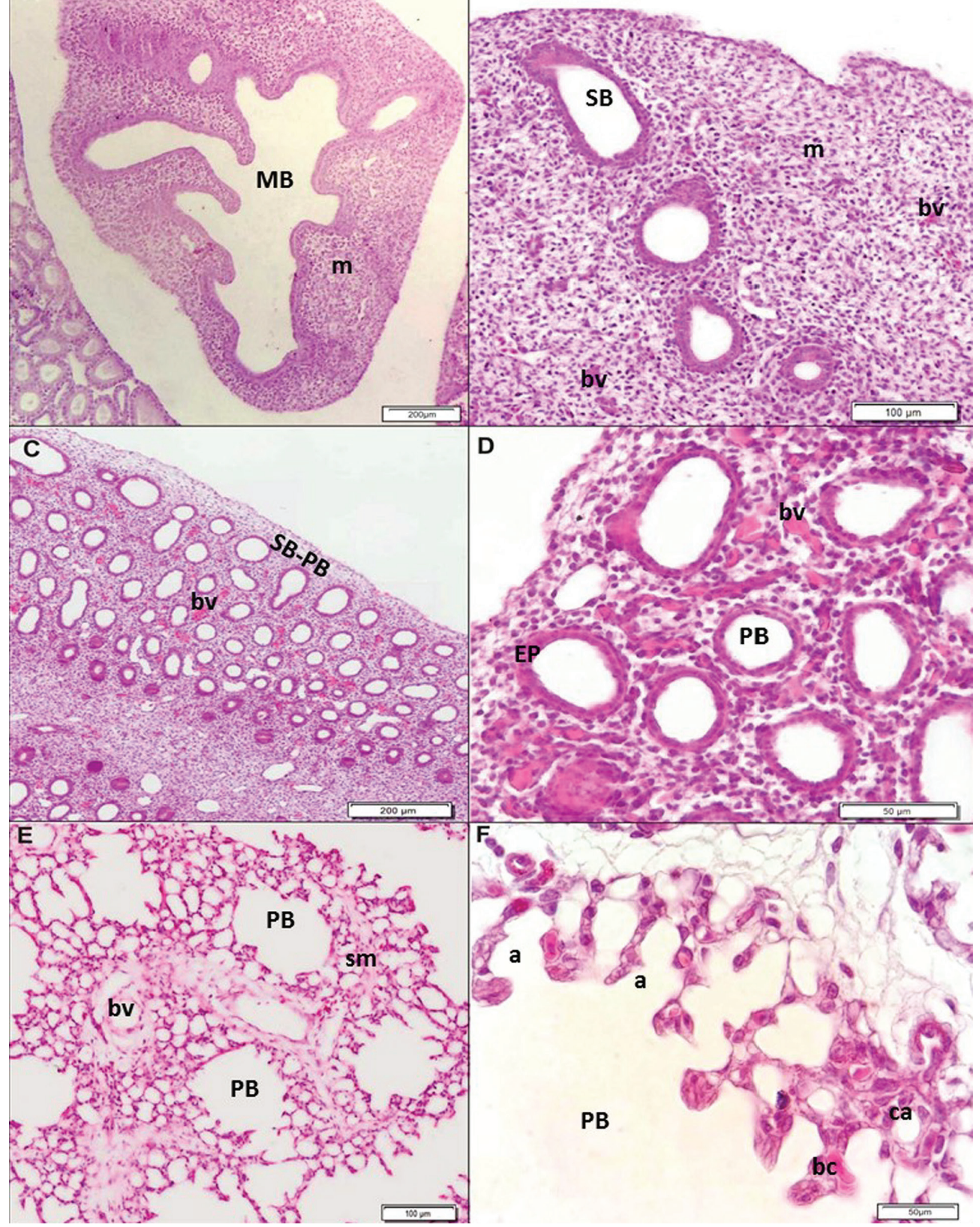

Fig.7. Embryo lung and Rhea americana foetuses at different ages of development. (A-F) Lung at 9, 12, 15, 18, 27 and 31 days respectively. (A) Branching of the main bronchus (MB) into the mesenchyme (m). HE, Bar $=200 \mu \mathrm{m}$. (B) Secondary bronchi (SB), mesenchyme (m), blood vessel (bv). HE, Bar $=100 \mu \mathrm{m}$. (C) Secondary bronchi originating parabronchi (SB-PB), with a large number of blood vessels (bv). HE, Bar $=200 \mu \mathrm{m}$. (D) Parabronchi (PB) with a simple cubic epithelium (EP) and blood vessels (bv) close to parabronchi. $\mathrm{HE}, \mathrm{Bar}=50 \mu \mathrm{m}$. (E) Is observed parabronchi (PB) with numerous air and blood vessels (bv) and smooth muscle (sm). $\mathrm{HE}, \mathrm{Bar}=$ $100 \mu \mathrm{m}$. (F) Parabronchial surface (PB) indicating the atria (a) with simple squamous epithelium and increased number of blood vessels associated with capillary air (ca), and blood capillaries (bc). HE, Bar $=50 \mu \mathrm{m}$. 

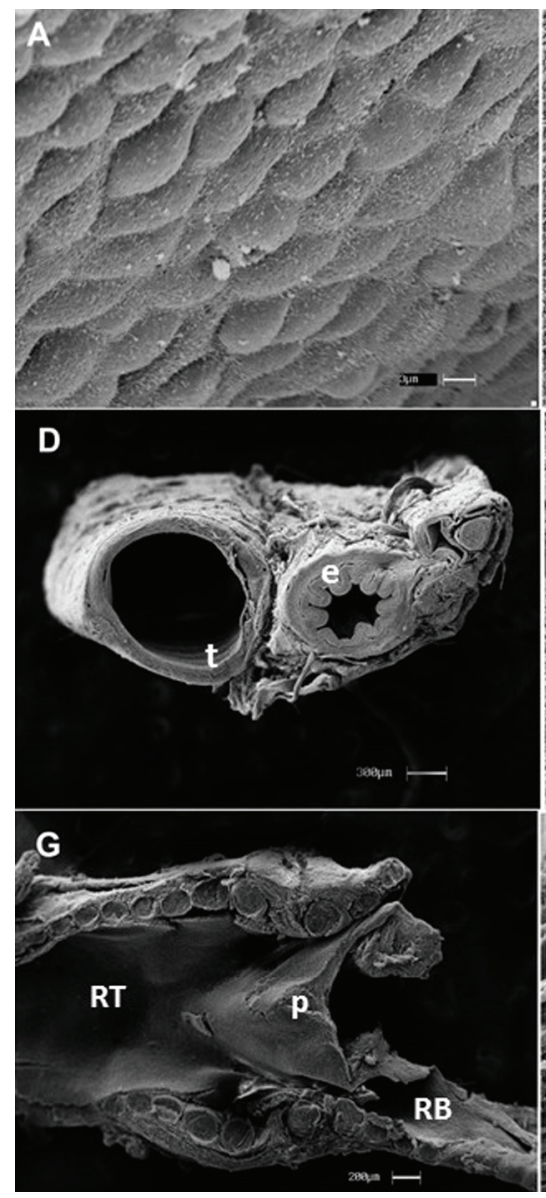

Fig.8. Scanning electron microscopy (SEM) of fragments of the respiratory organs of developing foetuses of Rhea americana. (A) Region of the rostral nasal cavity of a 15-day-old foetus, showing the mucosa with a layer of cuboidal cells. Bar $=3 \mu \mathrm{m}$. (B) Rostral region of the nasal cavity of a 30-day foetus with keratinized surface and cells sloughing off (cs). Bar = 100 $\mu$ m. (C) A 27-day foetal larynx with numerous eyelashes and goblet cells (GC). Bar $=30 \mu \mathrm{m}$. (D) Trachea (t) of a 21-day-old foetus; note the cartilaginous tube syntopy with the oesophagus (e). Bar $=300 \mu \mathrm{m}$. (E) Trachea epithelium with goblet cells and multiple eyelashes (GC) of a 30-day-old foetus. Bar $=10 \mu \mathrm{m}$. (F) Bronchiosyringeal region of a 21-day-old foetus showing cilia groups (ci). Bar $=10 \mu \mathrm{m}$. (G) A 21-day foetal syrinx longitudinal section showing the trachiosyringeal regions (RT), bronchiosyringeal (RB) and pessulus (p). Bar $=200 \mu \mathrm{m}$. (H) A 15-day foetal lung showing the parabronchi (PB) and blood vessel (bv). Bar $=30 \mu \mathrm{m}$. (I) A 27-day foetal lung with the main bronchus (BP), secondary bronchi (BS), and parabronchial surface comprising numerous atria. Bar $=300 \mu \mathrm{m}$.

The adventitia showed up vascularized and innervated. At those ages the hyaline cartilage pieces were formed.

\section{Lung}

The differentiation of the lung was characterized according to the stages of development of the ducts that form the intrapulmonary bronchial system and the presence/disposal of air and blood capillaries. Thus, the following stages were considered: pseudoglandular, bronchial, parabronchial and air capillary parabronchial. The pseudoglandular stage was characterized as a branch of the duct system (primary and secondary bronchi) that resembled an endocrine gland; the mesenchyme had cells with globular and occasional blood vessels. The bronchial stage was distinguished by its presentation of secondary bronchi projecting into the mesenchyme and the presence of blood vessels away from the bronchial epithelium. At this stage, some primordial parabronchi may be noted. In the parabronchial stage, there is a large number of formed parabronchi. These sprouted secondary bronchus intrapulmonary in rapid succession and lung tissue is more vascularized close to parabronchi. The air capillary parabronchial stage, corresponding to the most advanced stages of development, is characterized by the formation of the blood-air barrier (contact parabronchial epithelium with hair).

The rhea lung at EM9, still in the embryonic stage, consisted of little vascularized dense parenchyma with a large amount of vacuolated mesenchymal cells. Some circular areas with centripetal cells and an array of clusters of vacuolization and cell death could be seen. This developmental stage had branching ducts peculiar to the pseudoglandular stage (Fig.7A) and the primary and secondary bronchi exhibited epithelium composed of a basal layer of cuboidal cells and superficial squamous cells. Already in FE11 and FE12, secondary bronchi, coated in simple cubic epithelium, protruded into the mesenchyme, which was more highly vascularized and characteristic of the bronchial stage of this phase (Fig.7B).

Secondary bronchi were visualized giving rise to parabronchi in FE13 and FE15, a typical feature of the parabron- 
chial stage. The epithelium of parabronchi in that range remained simple cubic and interparabronchial vascularization was higher in FE15 as was the number of trained parabronchi (Fig.7C and 8H). The FE18 and FE21 are also classified at this stage, the mesenchyme being more cellularized in FE18 than in FE21. Furthermore, to the extent that development progresses, there is a greater proximity of blood vessels to parabronchi (Fig.7D). Furthermore, intrapulmonary bronchi that distinguished the histogenesis of hyaline cartilage surrounding the lumen were observed in the primary FE18.

The parabronchial epithelial cells undergo reorganization at FE27, FE30 and FE31, yielding numerous air vesicles (atria), formed by simple squamous epithelium and accompanied by air and blood capillaries featuring the capillary air parabronchial stage (Fig.7E,F). At this stage, in addition to the large amount of formed parabronchi, its radiation through the lumen of the secondary bronchi extending throughout the lungs was observed (Fig.8I). Concomitantly, smooth muscle bundles were observed on the atrial surface and interparabronchial region (Fig.7E).

\section{DISCUSSION}

The morphological features of the respiratory system of rheas throughout development are fundamental to understanding the particularities relating to growth, transformation and progression of various normal embryonic structural components and identifying elements that should influence their performance. According Bellairs \& Osmond (2005) epithelial-mesenchymal interactions play an important role in the differentiation of various developing regions.

Chicken embryos have been widely used by several authors for research relating to embryonic events in birds (Walsh \& McLelland 1978, Maina 2003a, 2003b, Alcântara et al. 2013). However, there is still a data gap in the literature concerning the morphological characteristics of the respiratory system during embryonic and foetal development in other birds, especially large ones, which restricts, in part, the discussion of our results to a comparison with data available for domestic chicken (Gallus gallus domesticus). In addition, the data obtained during the last stages of development observed in rheas, allows a comparison with that of other adult birds.

Thus, this study reveals some remarkable chronological differences in the various structural components of the respiratory system of the developing bodies of rheas in relation to other species of birds. However, many of these morphological characteristics are similar to those of other birds, considering the different times of incubation.

The nasal cavity of the bird is basically made up of three shells: a rostral nasal turbinate, middle turbinate and nasal turbinate flow, being completely divided by the nasal septum (Dyce et al. 2004, Bellairs \& Osmond 2005, Yokosuka et al. 2009). The rostral and middle turbinates observed in FE13 were also described by Yokosuka et al. (2009) to study the histological properties of the nasal cavity of the jungle crow (Corvus macrorhynchosn) at one year of age, the nasal concha indistinct flow as observed in this study. Yokosuka et al. (2009) add that the nasal concha flow is usually observed in the nasal cavity of birds with well-developed senses of smell.

Corroborating this study, Alcântara et al. (2013) identified in chicken embryos at 10 days of incubation, a shell with a typical respiratory epithelium, which was characteristic of rhea foetuses in the middle turbinate region at a proportionately later stage. The rostral nasal turbinate structure in 30-day rhea foetuses exhibited characteristics similar to those observed in the domestic chicken Gallus gallus (Kang et al. 2013) at one year of age, and this species displayed stratified squamous epithelium. The evolution of the microscopic aspects of the nasal turbinates of rheas shows major adaptations to functional training in this region.

In the structure of the laryngeal skeleton, besides the arytenoid and cricoide cartilage observed in the rhea foetuses, procricoid cartilage was identified in geese (Onuk et at. 2010), adult ostrich (Abidu-Figueiredo et al. 2012) adult quail Coturnix coturnix japonicum (Cevik-Demirkan et al. 2007) and rheas (Crole \& Soley 2012), and in a later study, was also found in different locations in puppies and adolescent animals. These changes in the anatomical position of procricoid cartilage during the postnatal period and its small size relative to the cricoid and arytenoid cartilage, as shown by these authors, can justify the fact that this structure has not been displayed in rhea embryos or foetuses in the studied phases.

In the laryngeal cartilage, at the most advanced foetal age analysed, i.e., 31 days incubation, the presence of hyaline cartilage surrounded by perichondrium was observed, without evidence of ossification centres, as described in young ostrich (Abidu-Figueiredo et al. 2012). In contrast, in adult domestic geese, cricoid and procricoid cartilage appeared to be completely ossified and the arytenoid cartilage showed regions of ossification (Onuk et al. 2010). According to Onuk et al. (2010), the rate of ossification of the laryngeal cartilage increase with age; hence, they proposed that this criterion can help to distinguish Young and adult birds. Thus, the absence of ossification centres in rhea foetuses are to be expected.

The morphology of the larynx in rhea foetuses (FE15 to FE21) has been described in chicken embryos at 10 and 14 days and the formation of two to four layers of cells has been observed in the epithelium lining the larynx (Walsh \& McLelland 1978). These authors also reported greater cell differentiation between 17 and 21 days, corresponding to the last stages of development in chickens, as was shown in rhea foetuses between FE27 and FE31. In young ostrich Struthio camelus, the caudal region of the larynx showed respiratory type pseudo-stratified epithelium, ciliated and cylindrical with the presence of goblet cells, similar to that seen in ostrich foetuses in the latter stages of development (Abidu-Figueiredo et al. 2012). Intraepithelial mucous glands were also observed in this study, along the laryngeal epithelium lining the cavity between FE27 and FE31 were observed by Cevik-Demirkan et al. (2007) in adult quails Coturnix coturnix japonicum. As described by Banks (1991), these glands typify the respiratory epithelium of the bird; however, they were not reported by Walsh \& McLelland (1978) in domestic fowl. 
During the tracheal development, characterized in rhea embryos and fetuses, the differentiation of the EM9 epithelial cells to the morphological formation observed in the last stages of development FE27 and FE31 was also seen in domestic chickens between 10 and 21 days old (Walsh \& Mclelland 1978), characterized in both species, typical respiratory epithelium of birds, in the most advanced stages of development.

According to Daniely et al. (2004), stem cells are capable of differentiating into cells and mucussecreting hair during normal morphogenesis of the tracheal epithelium. In this study, the identification of hair cells occurred in the late period, considering the incubation time of rheas relative to that observed in domestic hens, with pseudostratified epithelium with ciliated cells being reported in this species at six days (Alcântara et al. 2013). In contrast, Kalnins \& Porter (1969) observed in this same species, tracheal epithelium presenting cells with single primary cilium at 15 days of age. The presence of cilia is also observed in the trachea of quail and adult cockatiels (Cevik-Demirkan et al. 2007).

Consecutively, the remodelling of the apparent tracheal epithelium between FE27 and FE31 by the formation of intraepithelial glands at FE31 showed that at this stage, cellular organization presentes similarities to that which is observed in adult birds (Smith et al. 1987, Cevik-Demirkan et al. 2007). Though this age does not represent full foetal development in rheas, many morphological characteristics are sufficiently ready to take on a respiratory function.

As for the complete formation of the cartilaginous rings of the trachea, this study reported that in the late period in rhea foetuses, compared with that described for chickens at six days, the trachea was characterized as a long, flexible cartilaginous tube (Alcântara et al. 2013). In the adult parakeet Melopsittacus undulates, most tracheal cartilages had become calcified (Smith et al. 1987) by this time. During the last stages of development described here in rheas, the morphological structure of the syrinx showed similarities in relation to that observed in young and adult birds (Cevik-Demirkan et al. 2007, Khaksar et al. 2012, Yildiz et al. 2003). As described in rhea foetuses, the lining of the mucosa and submucosa and the outermost layer of the syrinx, the tunica adventitia, presented a cellular organization comparable to that observed in quail syrinx (Cevik-Demirkan et al. 2007), peru (Khaksar et al. 2012) and ostrich (Yildiz et al. 2003). Furthermore, Cevik-Demirkan et al. (2007) reported in quails the presence of intraepithelial glands observed in rhea to the maximum incubation age analysed in this study.

Subsequent to the syringeal region, the main extrapulmonary bronchi, also called mesobronchi, are coated by typical respiratory epithelium as was observed in ducks Anas platyrhynchos (Frank et al. 2006), parakeets (Smith et al. 1987) and Domestic hens (Lopez et al. 2000). As described by Alcântara et al. (2013), the structural components of the bronchial tubes are supported by cartilage plates as was observed in this study.

The lungs of birds present a complex network of anastomoses that make them exceptionally efficient compared with those of mammals (Maina 2003a). During lung morphogenesis, five stages of development are traditionally identified in mammals: embryonic, pseudoglandular, canalicular, saccular and alveolar (Perl \& Whitsett 1999, Maeda et al. 2007). However, these developmental stages are not evident in the lungs of birds (Maina 2003a). Taking into account the dynamics of lung morphogenesis observed in rheas, the phases characterized in this study are useful to identify the events that occur during lung development in rheas and can serve as parameters for studies in other birds.

Characteristics similar to the pseudoglandular stage in rhea lungs have been reported in domestic fowl at approximately eight days of incubation (Maina 2003a, $2003 \mathrm{~b}$ ). Other specific structures of the pulmonary parabronchial phase were revealed by Makanyaa et al. (2012) in ostrich embryos between 32 and 35 days of incubation and by Maina (2003a) and Maina (2003b) around the 10th day of incubation. In the last stages of development in rheas, the pulmonary parenchyma had a format similar to that observed in domestic chickens at 21 days of incubation (Jones \& Radnor 1972). In accordance with the foregoing by these authors, "with decreasing circular mesenchyme, an increase in the bronchial diameter assumed a pentagonal or hexagonal shape." At this stage, it is assumed that the atria are formed and the blood-air barrier is developed, as identified by Makanyaa et al. (2012) after 39 days in ostrich embryos, by Maina (2003a) and Maina (2003b) after 18 days in domestic chickens and by Runciman et al. (2005) after 32 days in Pelican Pelicanus conspicillatus, featuring the air capillary parabronchial stage as noted in rheas.

\section{CONCLUSIONS}

The analysis of the morphogenesis of the respiratory system of rhea embryonic and foetal stages contributes to the identification of the ontogenic pattern of this species in this organic system, a model not yet described. The morphogenesis of the characteristics of the rhea respiratory system showed similarities with those of other birds, while some differences are attributed to different incubation periods, species-specific genetic changes, different methodologies, changes in temperature and humidity in incubators and other factors.

The information generated in this research will still be useful for identifying pathologies that affect this system aimed at improving captive production systems. Furthermore, considering the dynamics of morphogenesis, the phases characterized in this study are important for identifying events that occur during the development of respiratory organs of rheas and may serve as parameters for studies in other birds.

Further investigation is needed to assess the genetic and molecular factors involved in the morphogenesis of this system in rheas.

Acknowledgements.- To the National Council of Scientific and Technological Development - CNPq 651 (Notice MCTI/CNPq/MEC/CAPES, Transversal Action no. 06/2011 Casadinho/Procad 652 552400/2011-4) for 
financial support, and to Diego Carvalho Viana, School of Veterinary Medicine and Animal Science, University of São Paulo, for the collaboration in photography.

\section{REFERENCES}

Abidu-Figueiredo M., Machado-Santos C., Bath F.V.C. \& Chagas M.A. 2012. Aspectos morfológicos da laringe do avestruz (Struthio camelus). Revta Bras. Med. Vet. 34:202-205.

Alcântara D., Rodrigues M.N, Franciolli A.L.R., Fonseca E.T., Silva F.M.O., Carvalho R.C., Fratini P., Sarmento C.A.P., Ferreira A.J.P. \& Miglino M.A. 2013. Embryonic development of endoderm in chicken (Gallus gallus domesticus). Microsc. Res. Techniq. 76:803-810.

Almeida H.M., Sousa R.P., Bezerra D.O., Olivindo R.F.G., Diniz A.N., Oliveira S.C., Feitosa M.L.T., Fortes E.A.M., Ferraz M.S., Carvalho Y.K.P., Menezes D.J.A. \& Carvalho M.A.M. 2015. Greater rhea (Rhea americana) external morphology atdifferent stages of embryonic and fetal development. Anim. Reprod. Sci. 162:43-51.

Banks W.J. 1991. Histologia veterinária aplicada. In: Sistema respiratório. Manole, São Paulo, p.499-517.

Bellairs R. \& Osmond M. 2005. The atlas of chick development. 2nd ed. Elsevier, London. 470p.

Cevik-Demirkan A., Haziroğlu R.M. \& Kürtül I. 2007. Gross morphological and histological features of larynx, trachea and syrinx in Japanese Quail. Anat. Histol. Embryol. 36:215-219.

Crole M. \& Soley J. 2012. Gross anatomical features of the tongue, lingual skeleton and laryngeal mound of Rhea americana (Palaeognathae, Aves): morpho-functional considerations. Zoomorphology 131:265-273.

Dani S. 1993. A ema (Rhea americana) biologia, manejo e conservação. Fundação Acangaú, Belo Horizonte, MG. 136p.

Daniely Y., Liao G., Dixon D., Linnoila I.R., Lori A., Randell S.H., Oren M. \& Jetten A.M. 2004. Critical role of p63 in the development of a normal esophageal and tracheobronchial epithelium. Am. J. Physiol. Cell. Physiol. 287:171-181.

Dyce K.M., Sack W.O. \& Wensing C.J.G. 2004. Tratado de Anatomia Animal. $2^{\underline{a}}$ ed. Guanabara, Rio de Janeiro.

Frank T., Walter I., Probst A. \& Konig H.E. 2006. Histological aspects of the syrinx of the male mallard (Anas platyrhynchos). Anat. Histol. Embryol. 35:396-401.

Jones A.W. \& Radnor C.J.P. 1972. The development of the chick tertiary bronchus. I. General development and the mode of production of the osmiophilic inclusion body. J. Anat. 113:303-324.

Khaksar Z., Kookhdan E.T. \& Parto P. 2012. A study on anatomy and histological structure of larynx in adult male and female turkeys. World J. Zool. 7:245-250.

Kang H., Yan M., Yu Q. \& Yang Q. 2013. Characteristics of nasal-associated lymphoid tissue (NALT) and nasal absorption capacity in chicken. Plos One 8(12):e84097.

Kalnins V.I. \& Porter K.R. 1969. Centriole replication during ciliogenesis in the chick tracheal epithelium. Z. Zellforsch. 100:1-30.
Lopez J., Cuesta N.E. \& Burrell M.A. 2000. Brush-like cells within bronchial epithelia of chicken lung (Gallus gallus). Histol. Histopathol. 15:487-491.

Macari M. 1994. Fisiologia respiratória, p.31-43. In: Ibid. (Ed.), Fisiologia Aviária Aplicada a Frangos de Corte. Funep/Unesp, Jaboticabal.

Maeda Y., Vrushank D. \& Whitsett J.A. 2007. Transcriptional control of lung morphogenesis. Physiol. Rev. 87:219-244.

Maina J.N. 2003a. A systematic study of the development of the airway (bronchial) system of the avian lung from days 3 to 26 of embryogenesis: a transmission electron microscopic study on the domestic fowl, Gallus gallus var. domesticus. Tissue Cell. 35:375-391.

Maina J.N. 2003b. Developmental dynamics of the bronchial (airway) and air sac systems of the avian respiratory system from day 3 to day 26 of life: a scanning electron microscopic study of the domestic fowl, Gallus gallus var. domesticus. Anat. Embryol. 207:119-134.

Makanyaa A.N., Koller T., Hlushchuk R. \& Djonov V. 2012. Pre-hatch lung development in the ostrich. Resp. Physiol. Neurobiol. 180:183-192.

Monteiro H.M.A. 2014. Morfologia externa no desenvolvimento embrionário e fetal de emas (Rhea americana Linnaeus, 1758) e histogênese do aparelho digestório. Tese de Doutorado, Universidade Federal do Piauí, Teresina. 94p.

Onuk B., Haziroğlu R.M. \& Kabak M. 2010. The gross anatomy of larynx, trachae and syrinx in goose (Anser anser domesticus). Kafkas Univ. Vet. Fak. Derg. 16:443-450.

Perl A.K.T. \& Whitsett J.A. 1999. Molecular mechanisms controlling lung morphogenesis. Clin. Genet.. 56:14-27.

Pollock C., Carpenter J.W. \& Antinoff N. 2005. Birds, p.135-344. In: Carpenter J.W. (Ed.), Exotic Animal Formulary. 3rd ed. Elsevier Saunders, St. Louis.

Runciman S., Seymour R.S., Baudinette R.V. \& Pearson J.T. 2005. An allometric study of lung morphology during development in the Australian pelican, Pelicanus conspicillatus, from embryo to adult. J. Anat. 207:365380.

Sick H. 2001. Ornitologia Brasileira. 3ª Impressão. Nova Fronteira, Rio de Janeiro. 912p.

Sigrist T. 2009. Guia de Campo Avis Brasilis: avifauna brasileira. Descrição das Espécies. Ed. Avis Brasilis, Vinhedo, SP. 600p.

Smith J.H., Meier J.L., Lampke C., Neill P.J.G. \& Box E. 1987. Microscopic and ultrastructural anatomy of the trachea and bronchi of Melopsittacus undulatus (Aves, Psittaciformes). Zoomorphology 107:1-10.

Walsh C.E. \& McLelland J. 1978. The development of the epithelium and its innervation in the avian extra-pulmonary respiratory tract. J. Anat. 125:171-182.

Yildiz H., Bahadir A. \& Akkoç A. 2003. A study on the morphological structure of syrinx in ostriches (Struthio camelus). Anat. Histol. Embryol. 32:187-191.

Yokosuka M., Hagiwara A., Saito T.R., Tsukahara N., Aoyama M., Wakabayashi Y., Sugita S. \& Ichikawa M. 2009. Histological properties of the nasal cavity and olfactory bulb of the Japanese jungle crow, Corvus macrorhynchos. Chem. Senses 34:581-593. 